\author{
Article \\ Doi 10.5943/mycosphere/8/7/9 \\ Copyright (c) Guizhou Academy of Agricultural Sciences
}

\title{
Mycosphere Essays 19: Recent advances and future challenges in taxonomy of coelomycetous fungi
}

\section{Wijayawardene $\mathrm{NN}^{1,2}$, Papizadeh $\mathrm{M}^{3}$, Phillips $\mathrm{AJL}^{4}$, Wanasinghe $\mathrm{DN}^{2}$, Bhat $\mathrm{DJ}^{2}$, Weerahewa HLD ${ }^{5}$, Shenoy $\mathrm{BD}^{6}$, Wang $\mathrm{Y}^{7}$ and Huang $\mathrm{YQ}^{1}$}

\author{
${ }^{1}$ College of Land and Environment, Shenyang Agricultural University, Shenyang 110866, China. \\ ${ }^{2}$ Center of Excellence in Fungal Research and School of Science, Mae Fah Luang University, Chiang Rai 57100, \\ Thailand \\ ${ }^{3}$ Microorganisms Bank, Iranian Biological Resource Centre (IBRC), Academic Centre for Education, Culture and \\ Research (ACECR), Tehran, Iran \\ ${ }^{4}$ Faculty of Sciences, Biosystems and Integrative Sciences Institute (BioISI), University of Lisbon, Campo Grande, \\ 1749-016 Lisbon, Portugal \\ ${ }^{5}$ Department of Botany, The Open University of Sri Lanka, Nawala, Nugegoda, Sri Lanka \\ ${ }^{6}$ CSIR-National Institute of Oceanography Regional Centre, Visakhapatnam 530017, Andhra Pradesh, India \\ ${ }^{7}$ Department of Plant Pathology, Agriculture College, Guizhou University, Guiyang 550025, People's Republic of \\ China
}

Wijayawardene NN, Papizadeh M, Phillips AJL, Wanasinghe DN, Bhat DJ, Weerahewa HLD, Shenoy BD, Wang Y, Huang YQ 2017 - Mycosphere Essays 19: Recent advances and future challenges in taxonomy of coelomycetous fungi. Mycosphere 8(7), 934-950, Doi $10.5943 /$ mycosphere/8/7/9

\begin{abstract}
The application of molecular phylogenetic methods has provided a better understanding of the taxonomy and evolution of coelomycetous fungi. Providing taxonomic placements for orphan genera, re-visiting historic genera, resolving species complexes and polyphyletic genera are progressing with new data continually immerging. Taxonomists need to implement the usage of adopted names of pleomorphic fungi after the introduction of Art. 59.1. In this paper, we summarize the recent advances and future potentials of taxonomic studies of coelomycetous studies.
\end{abstract}

\section{Keywords - morphology - phylogeny - pleomorphism - species complexes}

\section{Introduction}

Hyde et al (2011) asked the question if morphology was still relevant in the molecular world. Since then, the application of DNA and protein sequence data in fungal taxonomy has become common practice amongst mycologists and a standard in most publications (Hyde et al. 2013, Ariyawansa et al. 2015). Within the coelomycetous fungi, introduction of new genera or species (Maharachchikumbura et al. 2012, Crous et al. 2015a, b, c, 2016, Li et al. 2015, 2016, Dai et al. 2016, Hyde et al. 2016, Wijayawardene et al. 2016, Tibpromma et al. 2017), resolving species complexes (Phillips et al. 2012, Alves et al. 2014, Damm et al. 2014) and linking sexual-asexual genera (Wijayawardene et al. 2014b, Rossman et al. 2015a, b) or linking asexual-asexual genera (i.e. synasexual) (Crous et al. 2009) are now almost entirely based on sequence analyses. Sequence data analyses have enabled more accurate and reliable delimitation of generic and species boundaries. However, despite these revolutionary approaches in fungal taxonomy, morphology 
remains important when introducing new taxa, as many coelomycetous genera lack sequence data and have yet to be re-visited since their introduction.

In this paper, we discuss recent advances in taxonomy of coelomycetous fungi and outline future directions.

\section{Species complexes - Cryptic species}

Recent phylogenetic analyses have shown that some species are a complex of often morphologically cryptic species, which means that species differentiation is problematic when relying only on morphological characters (Phillips et al. 2008, 2012, Yang et al. 2009, Alves et al. 2014, Damm et al. 2014, Jayawardena et al. 2016). The concept of cryptic species has been discussed in different life modes, including lichen-forming taxa (Crespo \& Lumbsch 2010), plant pathogens (Phillips et al. 2012, Damm et al. 2014, Alves et al. 2014, Hyde et al. 2014), and saprobes (Udayanga et al. 2012, 2014). Jeewon \& Hyde (2016) provide guidelines to the considerations needed when introducing a new species.

Sequence based taxonomic studies have revealed that several coelomycetous taxa are species complexes, which have now been split into several new species (Maharachchikumbura et al. 2012, Udayanga et al. 2012). Most of these species complexes appear to occur within plant pathogens and thus, recent advances in taxonomy can directly impact on other disciplines such as quarantine/biosecurity and agriculture. Recent changes in the taxonomy of some Colletotrichum and Neofusicoccum taxa and the bar code gene regions used to differentiate the species complexes are outlined in Table 1.

Although there was a suggestion that Colletotrichum siamense is a species complex (Sharma et al. 2015), Liu et al. (2016) tested this hypothesis using a global strain collection based on the GCPSR and coalescent methods. It was reported that their analyses did not support the recognition of any independent evolutionary lineages within $C$. siamense sensu lato as distinct species. They concluded that reproductive isolation, geographic and host plant barriers to gene flow are absent in $C$. siamense sensu lato. Consequently, Colletotrichum communis, C. dianesei, C. endomangiferae, $C$. hymenocallidis, $C$. jasmini-sambac and $C$. murrayae were synonymised under C. siamense. It may be highlighted here that although Liu et al. (2016) employed sophisticated phylogenetic and statistical methods, the main dataset had only 161 informative characters. It remains to be seen whether the hypothesis, that $C$. siamense is a single species, will pass through genome-wide sequence analysis in coming years.

\section{Polyphyletic genera and morphologically similar genera}

Some genera (e.g. Camarosporium, Phoma) have been shown to be polyphyletic, being linked to more than one sexual morph or have been placed in more than one family (Kirk et al. 2008, Schoch et al. 2009, de Gruyter et al. 2013, Aveskamp et al. 2010, Hyde et al. 2011, Wijayawardene et al. 2012). Other genera such as Cytoplea and Cyclothyrium share close morphological characters, and establishing generic boundaries was difficult (Sutton 1980, Wijayawardene et al. 2016).

\section{a. Camarosporium Schulzer}

The heterogenic nature of Camarosporium was mentioned by Sutton (1980). Camarosporium sensu stricto resides in Pleosporineae, Pleosporales (Wijayawardene et al. 2014a, 2016) but Wijayawardene et al. (2014c) showed that an isolate of $C$. propinquum from Italy resided in Didymosphaeriaceae, Massarineae, Pleosporales Hence, Wijayawardene et al. (2014c) introduced Pseudocamarosporium to accommodate $C$. propinquum and four other species of Pseudocamarosporium.

Crous et al. (2013) introduced C. psoraleae Crous \& M.J. Wingf., however, this species has paraphyses and produces microconidia in culture, features that have not been reported in Camarosporium sensu stricto (Sutton 1980). In phylogenetic analyses, Wijayawardene et al. (2014c) 
showed that $C$. psoraleae belongs in Didymosphaeriaceae and is a sister clade to Pseudocamarosporium; therefore, Paracamarosporium was introduced as a new genus.

Table 1 Recently resolved species complexes within Colletotrichum spp. and Neofusicoccum spp. and gene regions used

\begin{tabular}{|c|c|c|c|}
\hline Species complex & $\begin{array}{l}\text { Currently known } \\
\text { species }\end{array}$ & Gene regions used & References \\
\hline C. acutatum & 31 & $\begin{array}{l}\text { ITS, ACT, TUB2, CHS-1, } \\
\text { GAPDH, HIS3 }\end{array}$ & Damm et al. $2012 \mathrm{a}$ \\
\hline C. boninense & 15 & $\begin{array}{l}\text { ITS, ACT, TUB2, CHS-1, } \\
\text { GAPDH, HIS3, CAL }\end{array}$ & Damm et al. 2012b \\
\hline C. destructivum & 16 & $\begin{array}{l}\text { ITS, GAPDH, CHS-1, HIS3, } \\
\text { ACT, TUB2 }\end{array}$ & Damm et al. 2014 \\
\hline C. gloeosporioides & $\begin{array}{l}22 \text { and one sub } \\
\text { species }\end{array}$ & $\begin{array}{l}\text { ACT, CAL, CHS-1, GAPDH, } \\
\text { ITS }\end{array}$ & Weir et al. 2012 \\
\hline Neofusicoccum parvum & 7 & ITS, tef, tub2 & $\begin{array}{l}\text { Phillips et al. 2012, } \\
\text { Dissanayake et al. } \\
2016\end{array}$ \\
\hline
\end{tabular}

Crous et al. (2015b) found that several Paraconiothyrium species grouped with Paracamarosporium and Pseudocamarosporium. Thus, the generic boundaries of Paracamarosporium and Pseudocamarosporium was expanded to include paraconiothyrium-like taxa. Neocamarosporium is not congeneric with Camarosporium sensu stricto, and Wijayawardene et al. (2016) showed that it resides in Pleosporaceae.

Camarosporium hederae, introduced by Ellis \& Everhart (1900), has brown, phragmosporous conidia, but Camarosporium sensu stricto has muriform conidia (Sutton 1980). Wijayawardene et al. (2015) examined two taxa from China and Germany that were morphologically close to $C$. hederae. However, phylogenetic studies showed that these taxa reside in Lentitheciaceae, Pleosporales, and they were placed in the new genus Phragmocamarosporium, typified with $P$. platani Wijayaw.

Suttonomyces Wijayaw. et al. (in Massarinaceae fide Wijayawardene et al. 2015), Didymello camerosporium Wijayaw. et al. (in Didymellaceae fide Wijayawardene et al. 2016), and Melanocamarosporium Wijayaw. et al. (in Melanommataceae fide Wijayawardene et al. 2016) have also been introduced to accommodate morphologically similar, but phylogenetically distinct, camarosporium-like taxa. Wanasinghe et al. (2014) introduced Murilentithecium Wanasinghe et al. (Lentitheciaceae) with Camarosporium-like asexual morph.

Unfortunately, the type species of Camarosporium, C. quaternatum (Hazsl.) Schulz. does not have ex-type strains and thus needs to be epitypified. More than 500 species epithets are listed in Index Fungorum (2017), many of which are based on host association. To confirm their correct generic placement, they would all need to be re-collected, epitypified and sequenced. DNA sequence analyses show the placements of Camarosporium-like taxa in Pleosporales (Fig. 1).

\section{Phoma-like taxa}

Phoma is a significant plant pathogenic genus and comprises many species epithets (Index Fungorum 2017). Saccardo (1884) and Sutton (1980) broadly defined the generic concept as thinwalled pycnidia containing aseptate, hyaline, short conidia produced by monophialidic, doliiform to flask-shaped conidiogenous cells occurring on herbaceous substrates. However, in its broad definition, Phoma also harbours taxa with thick-walled pycnidia, or even septate conidia and also elongate conidia in axenic culture (Boerema 1997, Boerema et al 2004). Moreover, Phoma was divided into nine sections by Boeremia et al. (2004): sect. Phoma, Heterospora, Paraphoma, Peyronellaea, Phyllostictoides, Sclerophomella, Plenodomus, Macrospora and Pilosa. 


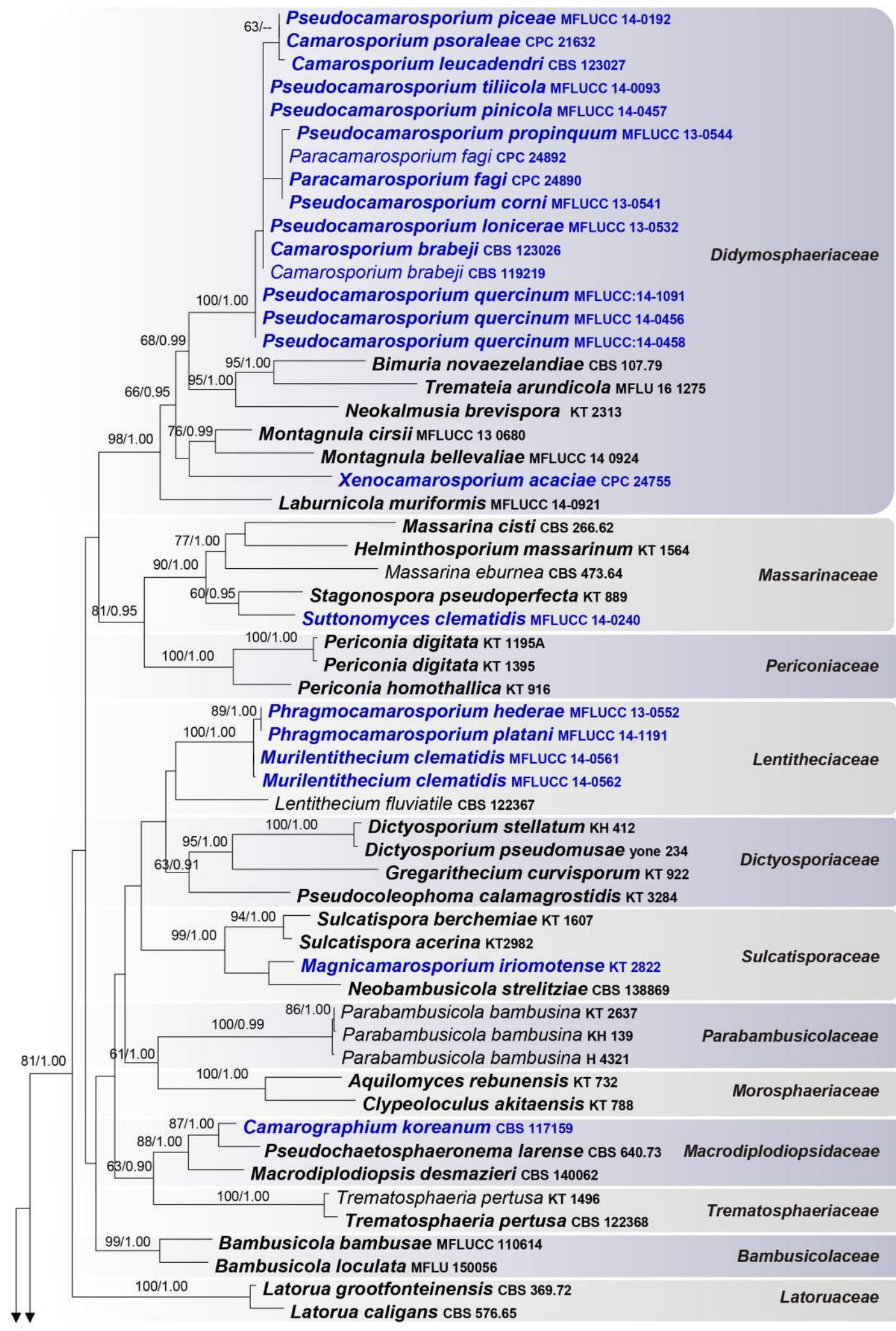

Fig. 1 - The best scoring RAxML tree of distribution of Camarosporium-like taxa generated from analyses of combined of LSU, SSU and TEF1- $\alpha$ sequence data. Bootstrap values of ML analyses $(>60 \%)$ resulting from 1000 bootstrap replicates and Bayesian posterior probabilities above 0.95 resulting from 5,000,000 replicates are given at the nodes. The original strain numbers are given after the species names. Classes are differentiated with alternative colours in the right justified column. The tree is rooted to Hysterium pulicare (CBS 123337) and Hysterobrevium mori (CBS 123563). 


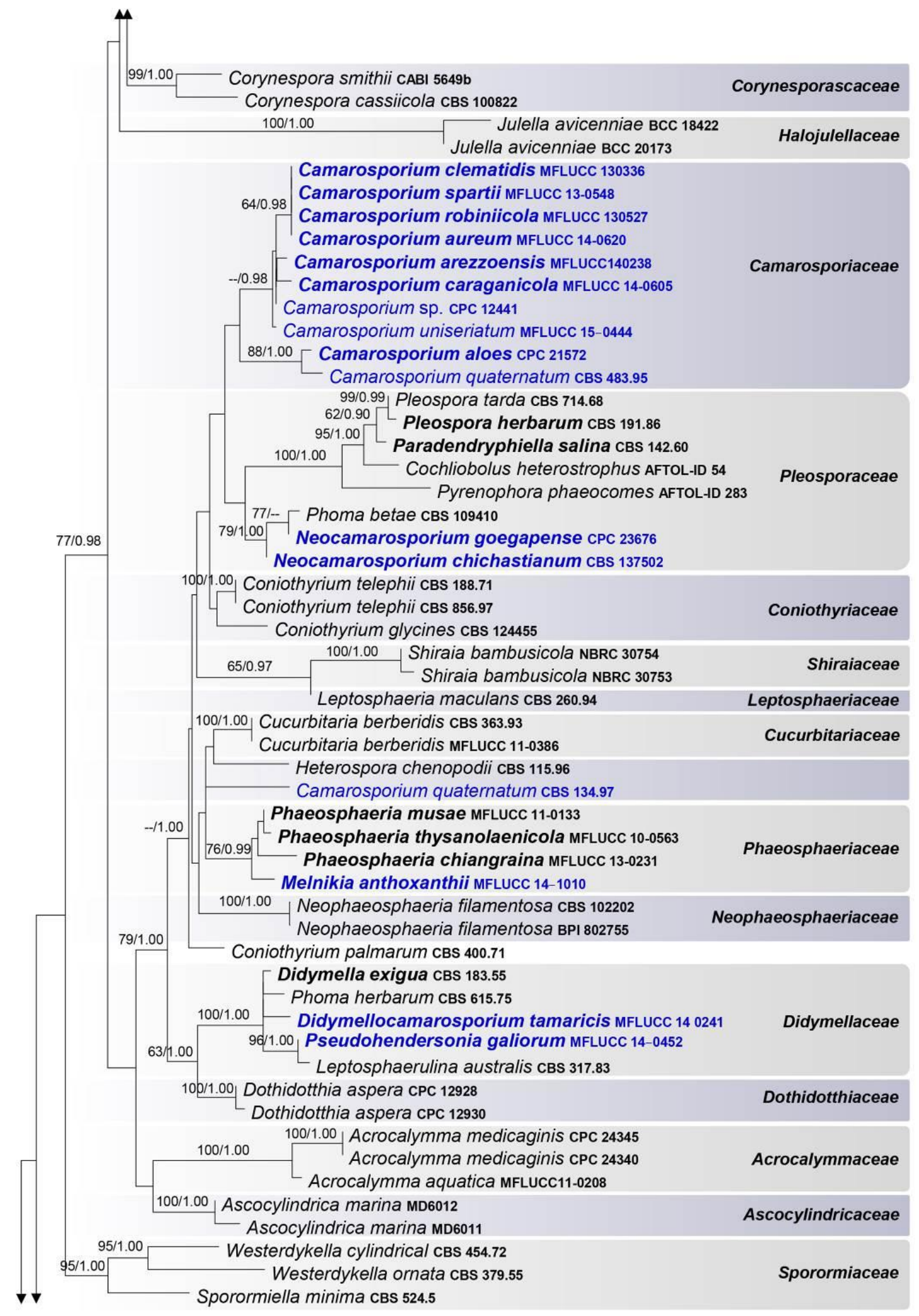

Fig. 1- Continued

Phoma-like asexual morphs are one of the most abundant fungal taxa and can be treated as one of the most common asexual morph of Pleosporinae in Pleosporales; the largest order of Dothideomycetes (de Gruyter et al. 2009, 2010, Aveskamp et al. 2010; Hyde et al. 2011, 2013, Wijayawardene et al. 2012). The phylogenetic placement of Phoma sensu stricto was confirmed in Didymellaceae (de Gruyter et al. 2009, Aveskamp et al. 2010). 


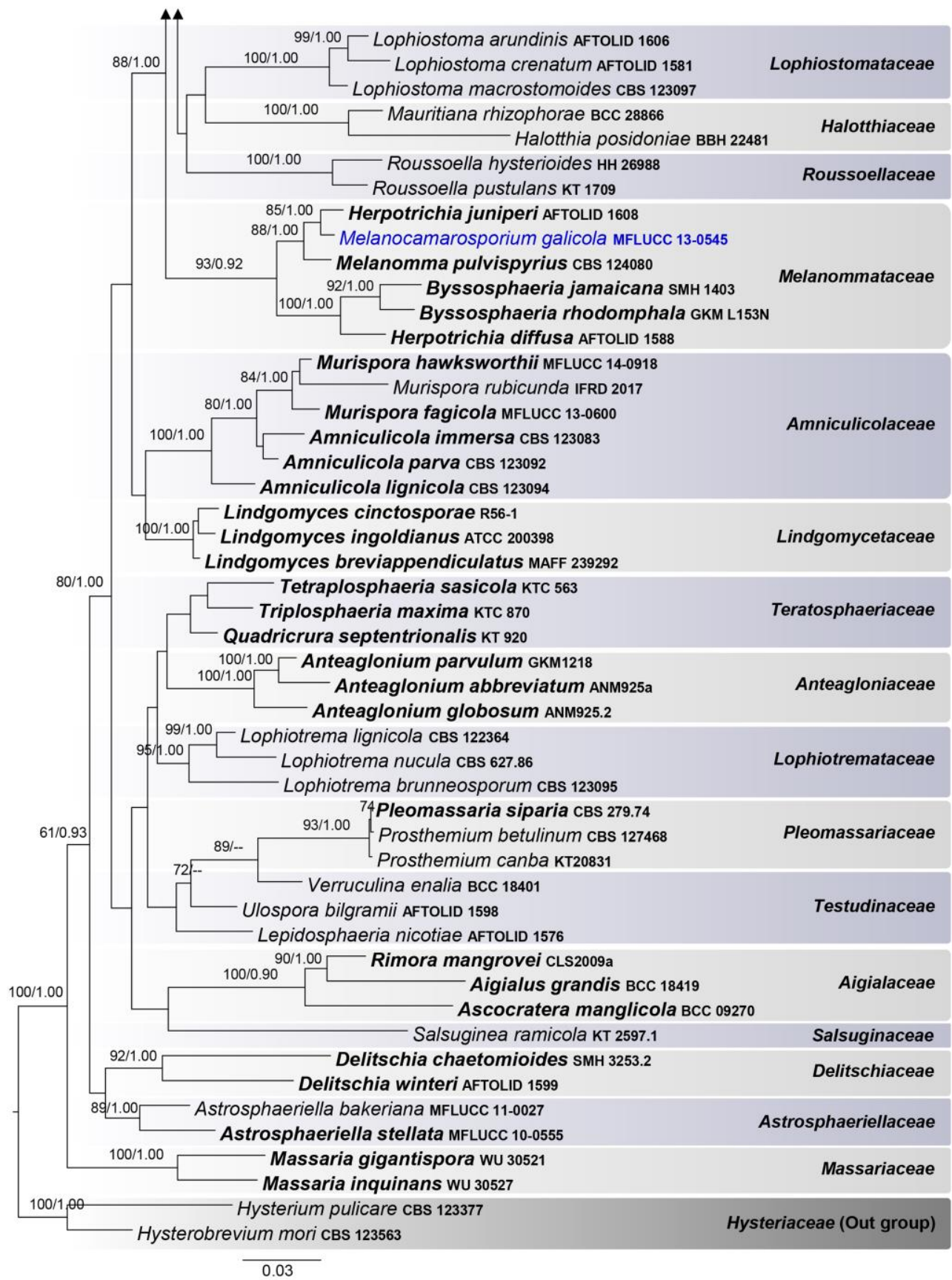

Fig. 1- Continued

However, several phoma-like taxa cluster in different families of Pleosporineae and thus several genera have been introduced (de Gruyter et al. 2010, 2013) to accommodate these variants. Table 2 summarizes the recently introduced phoma-like genera in Pleosporales. Fig. 2 shows the placements of phoma-like taxa in Pleosporales.

\section{Coniothyrium-like taxa}

Conidial characters of coniothyrium-like taxa are inadequate to distinguish genera merely based on morphology and, therefore, recent taxonomic studies have relied totally on sequence data analyses (Wijayawardene et al. 2016). Sutton (1980) mentioned that Coniothyrium sensu stricto comprises species that produce 0-1-septate conidia but added that 'the majority of species described in Coniothyrium were not congeneric with the type species'. Sutton (1980) defined Microsphaeropsis for the taxa with phialidic conidiogenesis and retained species with annellidic conidiogenesis in Coniothyrium. Verkley et al. (2004) showed that coniothyrium-like taxa are not monophyletic and several taxa resided in Didymosphaeriaceae. 
Table 2 Phoma-like genera introduced since Kirk et al. (2008)

\begin{tabular}{lll}
\hline Genus & Family & Reference \\
\hline Allophoma & Didymellaceae & Chen et al. 2015 \\
Boeremia & Didymellaceae & Aveskamp et al. 2010 \\
Calophoma & Didymellaceae & Chen et al. 2015 \\
Heterophoma & Didymellaceae & Chen et al. 2015 \\
Heterospora & Leptosphaeriaceae & de Gruyter et al. 2013 \\
Neoascochyta & Didymellaceae & Chen et al. 2015 \\
Neodidymelliopsis & Didymellaceae & Chen et al. 2015 \\
Nothophoma & Didymellaceae & Chen et al. 2015 \\
Paraboeremia & Didymellaceae & Chen et al. 2015 \\
Paraleptosphaeria & Leptosphaeriaceae & de Gruyter et al. 2013 \\
Phomatodes & Didymellaceae & Chen et al. 2015 \\
Pyrenochaetopsis & Cucurbitariaceae & de Gruyter et al. 2009 \\
Subplenodomus & Leptosphaeriaceae & de Gruyter et al. 2013 \\
Xenodidymella & Didymellaceae & Chen et al. 2015
\end{tabular}

Since Verkley et al. (2004), (Table 3), several coniothyrium-like taxa have been introduced and the generic concept is totally based on DNA sequence analyses. In recent years, new taxa have been introduced that are morphologically very similar (Phukhamsakda et al. 2016a, Wijayawardene et al. 2016).

The introductions are based on phylogenetic data, however in many cases the coelomycete morph is described first and then the sexual morph is found and introduced later (E.g. Pseudocamarosporium fide Wanasinghe et al. in prep.). This is likely to happen more and more in the future.

\section{Genera with many species epithets and host based species delimitation}

In the past, species in several genera were introduced based on host association, and this caused a proliferation of names (e.g. in Ascochyta, Camarosporium, Diplodia). Slippers et al. (2004) stated that the host is not an important factor in Botryosphaeriaceae species differentiation and, thus, Phillips et al. (2012) predicted that 'many of the names in Diplodia are likely to be synonyms'. However, Phillips et al. (2012) did provide several examples of Diplodia species that show some host specificity. Thus, it cannot be assumed that genera with many species epithets, but lacking sequence data, can be either consolidated into fewer species or remain in a 'host-based' system of classification. Several recent studies introduced new species based on host association and discussed the limitation of occurrence of some species on certain host plants (Chen et al. 2015).

Therefore, re-collecting species that were introduced based on host association and epitypification is an essential step towards resolving their taxonomic status. Besides, this could also affect two other aspects.

1. Some species may not be host-specific, and occur on a range of host plants. Hence one species may have many synonymous epithets since the species occurs on different hosts. DNA sequence analyses are needed to determine whether different species epithets belong to the one species or to different species.

2. Even though morphologically similar, some taxa differ in phylogeny, thus belonging to different genera. In earlier taxonomic works, certain taxa were named based on morphology and host association. Hence, particular species could be named under an incorrect generic name. As Ariyawansa et al. (2014) suggests, re-collecting taxa is essential to clarify the phylogenetic species/ generic boundaries and epitypification of certain species. e.g. Pseudocamarosporium propinquum fide Wijayawardene et al. (2014c).

Dayarathne et al. (2017) further discussed the necessity of utilization of old names in current classification and nomenclature. 


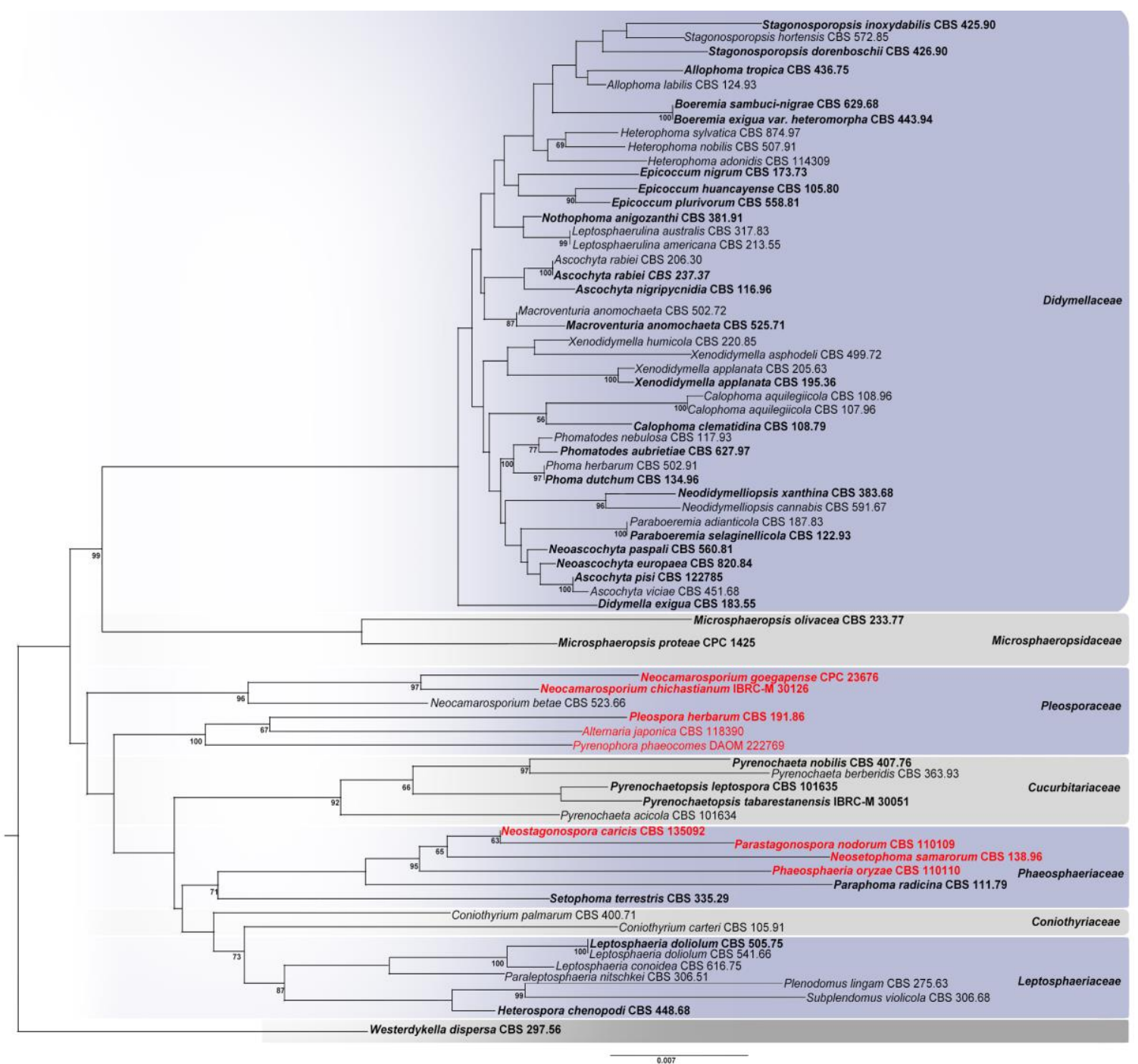

Fig. 2 - The best scoring ML tree of distribution of phoma-like taxa generated from analyses of combined dataset of LSU, ITS, RPB2 and $\beta$-tubulin sequences. Bootstrap values of ML analyses $(>50 \%)$ resulting from 1000 bootstrap replicates are given at the nodes. The original strain numbers are given after the species names. Families are differentiated with alternative colours in the right justified column. The tree is rooted to Westerdykella dispersa (CBS 297.56). Non-phomalike taxa are shown in red. Ex-type strains are shown in bold.

However, recent study of Ascomycota by Wijayawardene et al. (2017) recognised that naming newly collected taxa based on old name is much more complicated as some genera have not been re-visited for decades.

\section{Need to re-visit poorly known taxa}

Approximately 600 genera of coelomycetous fungi lack sequence data and, in general, have not been linked to a sexual morph or placed in a natural taxonomic position (Wijayawardene et al. 2012). Many 'historic genera and species were previously studied on the basis of morphology alone and without any cultures. It is essential to obtain and maintain cultures of fungi since DNA-based identification is based largely on cultures (Abd-Elsalam et al. 2010). Many genera have not been revisited since they were first described and it may be difficult to gather detailed illustrations and descriptions of these genera (Wijayawardene et al. 2016).

In some cases, species lack a type specimen or the specimens are in poor condition and therefore re-visiting such species is difficult. For example, Sutton (1975) stated that the type material of Coryneum nigrellum Lacroix is unavailable in Paris herbarium and he thus treated it as a doubtful species. 
Table 3 Coniothyrium-like genera introduced since Verkley et al. (2004)

\begin{tabular}{lll}
\hline Taxon & Taxonomic placement & Reference \\
\hline $\begin{array}{l}\text { Alloconiothyrium } \\
\text { Forliomyces }\end{array}$ & $\begin{array}{l}\text { Didymosphaeriaceae } \\
\text { Sporormiaceae }\end{array}$ & Verkley et al. 2014 \\
& Phukhamsakda et al. 2016a \\
Paulkirkia & Floricolaceae & Wijayawardene et al. 2016 \\
Verrucoconiothyrium & Didymosphaeriaceae & Crous et al. 2015b \\
Xenoconiothyrium & Teratosphaeriaceae & Crous et al. 2011 \\
\hline
\end{tabular}

As the type material of Coryneum nigrellum is unavailable, Wijayawardene et al. (2016) described a new species, $C$. pruni Wijayaw. et al. on Prunus sp., the same host from which $C$. nigrellum was recorded. Such a move brings up the question of 'why do we retain names of doubtful species or genera?'

Sutton \& Dyko (1989) treated Diplodia pinea (Desm.) Kickx., a pine pathogen, as a synonym of Sphaeropsis sapinea (Fr.) Dyko \& Sutton. However, Phillips et al. (2013) re-examined Sphaeria pinea Desm. (Desmaziéres No 1277 in PC, basionym of D. pinea) and concluded that the smaller conidia of this species differentiate it from Sphaeria sapinea, the basionym of Diplodia sapinea. Furthermore, Saccardo (1880) introduced Sphaeropsis for Diplodia species with brown, aseptate conidia and Phillips et al. (2013) showed that Sphaeropsis sensu stricto (based on Sphaeropsis visci) is phylogenetically distinct from Diplodia sensu stricto. Thus, it is important to re-visit genera with a large number of species and compare the findings with sequence data analyses.

Recent studies by Crous et al. (2015a, b, c) and Wijayawardene et al. (2016) discussed the taxonomic status of several coelomycetous taxa including historic genera. Re-visiting genera is important to clarify the validity of some genera such as Microdiplodia and Pestalotia (Wijayawardene et al. 2016).

\section{Genera sharing close morphologies with hyphomycetous taxa}

Traditional taxonomy, based largely on morphology, distinguished coelomycetous and hyphomycetous taxa primarily on the sporulating structures or conidiomata (Kendrick \& Nag Raj 1979). Kendrick (2000) stated that 'the production of conidia in enclosed structures or the absence of such enclosure' is the basic criterion to define a particular fungus as coelomycetous or hyphomycetous. Some genera, such as Scolicosporium have been treated as hyphomycetous in some studies (Spooner \& Kirk 1982, Seifert et al. 2011).

However, Wijayawardene et al. $(2013,2016)$ showed that the genus Scolicosporium is distinguished by their conidiomata produced beneath the plant integument and thus concluded it is coelomycetous. Confusion among taxonomists on conidiomatal structure (specially qualifying acervuli and sporodochia) has an effect on morphology-based identification and causes further misidentifications. Wijayawardene et al. (2016) pointed out the importance of following basic criteria in Kendrick \& Nag Raj (1979) to determine whether a conidiomata is an acervulus or a sporodochium. Thus, acervulus can be recognized as,

1. The hymenium develops beneath an integument entirely of host origin

2. Conidiogenous cells are restricted to the floor of the cavity

3. At maturity, there is usually a split of the host integument, and considerable exposure of the relatively flat hymenium

4. The hymenium layer arises from a more or less well developed pseudoparenchymatous stroma that forms at some level within the tissue of the host (Adopted from Kendrick \& Nag Raj 1979)

Wijayawardene et al. (2016) suggested observing a series of vertical sections of immature and mature conidiomata before they can be regarded as sporodochia or acervuli. 
Table 4 Summary of adopted names and suppressed names of pleomorphic coelomycetous genera (Agreeing to Article 59.1) (Modified table from Wijayawardene et al. 2016)

\begin{tabular}{|c|c|c|}
\hline Adopted names & $\begin{array}{l}\text { Suppressed name(s) (sexual, asexual } \\
\text { or synasexual) }\end{array}$ & References \\
\hline Apiognomonia Höhn. 1917 & Discula Sacc. 1884 & Rossman et al. $2015 \mathrm{a}$ \\
\hline Arthrinium $\mathrm{Kunze}^{+}$ & Apiospora Sacc. & $\begin{array}{l}\text { Senanayake et al. 2015, Réblová et } \\
\text { al. } 2016\end{array}$ \\
\hline Camarosporula Petr. & Anthracostroma Petr. & Rossman et al. $2015 b$ \\
\hline Ascodichaena Butin & Polymorphum Chevall. & Johnston et al. 2014 \\
\hline Blumeriella Arx & $\begin{array}{l}\text { Microgloeum Petr., Phloeosporella } \\
\text { Höhn. }\end{array}$ & Johnston et al. 2014 \\
\hline $\begin{array}{l}\text { Botryohypoxylon Samuels \& J.D. } \\
\text { Rogers }\end{array}$ & Iledon Samuels \& J.D. Rogers & $\begin{array}{l}\text { Wijayawardene et al. 2014b, } \\
\text { Rossman et al. 2015b }\end{array}$ \\
\hline Botryosphaeria Ces. \& De Not. & Fusicoccum Corda & $\begin{array}{l}\text { Phillips et al. 2013, Wijayawardene } \\
\text { et al. } 2014 \mathrm{~b}\end{array}$ \\
\hline Capnodium Mont. & Polychaeton (Pers.) Lév. & $\begin{array}{l}\text { Chomnunti et al. 2011, Rossman et } \\
\text { al. } 2015 \text { b }\end{array}$ \\
\hline Chaetomella $\quad$ Fuckel $\quad(=$ & Zoellneria Velen. & Johnston et al. 2014 \\
\hline $\begin{array}{l}\text { Volutellospora Thirum. \& P.N. } \\
\text { Mathur } \\
=\text { Harikrishnaella } \\
\text { A.K. Sarbhoy) }\end{array}$ & & \\
\hline $\begin{array}{l}\text { Chlorociboria Seaver ex C.S. } \\
\text { Ramamurthi et al. }\end{array}$ & Dothiorina Höhn & Johnston et al. 2014 \\
\hline Coma Nag Raj \& W.B. Kendr. & Ascocoma H.J. Swart & Johnston et al. 2014 \\
\hline Coniella Höhn. & $\begin{array}{l}\text { Pilidiella Petr. \& Syd., Schizoparme } \\
\text { Shear }\end{array}$ & Alvarez et al. 2016 \\
\hline Coryneum Nees & Pseudovalsa Ces. \& De Not. & Rossman et al. 2015a \\
\hline Crumenulopsis J.W. Groves & Digitosporium Gremmen & Johnston et al. 2014 \\
\hline Cyclopeltis Petr. & Cyclopeltella Petr. & $\begin{array}{l}\text { Wijayawardene et al. 2014b, } \\
\text { Rossman et al. 2015b }\end{array}$ \\
\hline Cryptosporella & Disculina Höhn. & Rossman et al. $2015 \mathrm{a}$ \\
\hline Cytospora Ehrenb. & 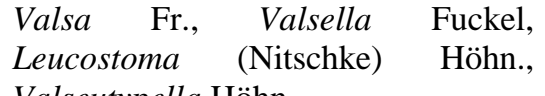 & Rossman et al. $2015 \mathrm{a}$ \\
\hline $\begin{array}{l}\text { Diplocarpon F.A. } \quad \text { Wolf } \\
\text { Entomopeziza } \text { Kleb.) }\end{array}$ & $\begin{array}{l}\text { Valseutypella Höhn., } \\
\text { Entomosporium } \\
\text { Bostrichonema Ces. }\end{array}$ & Johnston et al. 2014 \\
\hline Diaporthe Nitschk & Phomopsis (Sacc.) Bubák & $\begin{array}{l}\text { Udayanga et al. 2011, Rossman et } \\
\text { al. } 2015 \text { a }\end{array}$ \\
\hline Discosia Lib.* & Adisciso Kaz. Tanaka et al. & Wijayawardene et al. 2016 \\
\hline Elsinoë Racib. & Sphaceloma de Bary & Hyde et al. 2013 \\
\hline Cryphonectria Sacc. \& D. Sacc. & Endothiella Sacc. 1906 & Rossman et al. 2015a \\
\hline Godronia Moug. \& Lév. & $\begin{array}{l}\text { Sphaeronaema Fr., Topospora Fr., } \\
\text { (= Mastomyces Mont. } \\
=\text { Clinterium Fr.), } \\
\text { Fuckelia Bonord., Chondropodiella } \\
\text { Höhn. }\end{array}$ & Johnston et al. 2014 \\
\hline Gremmeniella M. Morelet & Brunchorstia Erikss. & Johnston et al. 2014 \\
\hline Heterosphaeria Grev. & Heteropatella Fuckel & Johnston et al. 2014 \\
\hline Hyalotiopsis Punith. & Ellurema Nag Raj \& W.B. Kendr. & $\begin{array}{l}\text { Wijayawardene et al. 2016; } \\
\text { Réblová et al. } 2016\end{array}$ \\
\hline Hypohelion P.R. Johnst. & Leptostroma Fr. & Johnston et al. 2014 \\
\hline Kellermania Ellis \& Everh. & Planistromella A.W. Ramaley & Hyde et al. 2013 \\
\hline Lecanosticta Syd. & Eruptio M.E. Barr & $\begin{array}{l}\text { Crous et al. 2009, Hyde et al. 2013, } \\
\text { Wijayawardene et al. 2014b }\end{array}$ \\
\hline Leptotrochila P. Karst. & Sporonema Desm. & Johnston et al. 2014 \\
\hline Massariovalsa Sacc. & Melanconiopsis Ellis \& Everh. & Rossman et al. 2015a \\
\hline Mastigosporella Höhn. & Wuestneiopsis J. Reid \& Dowsett & Rossman et al. 2015a \\
\hline Mazzantia Mont. & Mazzantiella Höhn. & Rossman et al. 2015a \\
\hline Melanconis Tul. \& C. Tul. & Melanconium Link & Rossman et al. $2015 \mathrm{a}$ \\
\hline Micraspis Darker & Periperidium Darker & Johnston et al. 2014 \\
\hline
\end{tabular}




\begin{tabular}{|c|c|c|}
\hline $\begin{array}{l}\text { Monochaetiellopsis B. Sutton \& } \\
\text { DiCosmo }\end{array}$ & Hypnotheca Tommerup & Johnston et al. 2014 \\
\hline Neofabraea H.S. Jacks. & $\begin{array}{l}\text { Phlyctema Desm. (= Allantozythia } \\
\text { Höhn) }\end{array}$ & Johnston et al. 2014 \\
\hline Ocotomyces H.C. Evans \& Minter & Uyucamyces H.C. Evans \& Minter & Johnston et al. 2014 \\
\hline Pezicula Tul. \& C. Tul. & $\begin{array}{l}\text { Cryptosporiopsis Bubák \& Kabát (= } \\
\text { Lagynodella Petr.) }\end{array}$ & Johnston et al. 2014 \\
\hline $\begin{array}{l}\text { Phacidiopycnis Potebnia } \\
\text { Discosporiopsis } \text { Petr.) }\end{array}$ & Potebniamyces Smerlis & Johnston et al. 2014 \\
\hline Phacidium Fr. & Ceuthospora Grev. & Johnston et al. 2014 \\
\hline Phaeosphaeria I. Miyake & Phaeoseptoria Speg. & Wijayawardene et al. 2014b \\
\hline Phyllosticta Pers. & Guignardia Viala \& Ravaz & Wikee et al. 2011 \\
\hline $\begin{array}{l}\text { Pilidium Kunze (= Sclerotiopsis } \\
\text { Speg.) }\end{array}$ & $\begin{array}{l}\text { Discohainesia Nannf., Hainesia } \\
\text { Ellis \& Sacc. }\end{array}$ & Johnston et al. 2014 \\
\hline Plagiostoma Fuckel & Diplodina Westend. & Rossman et al. $2015 b$ \\
\hline Ploioderma Darker. & Cryocaligula Minter & Johnston et al. 2014 \\
\hline Pragmopora A. Massal & Pragmopycnis B. Sutton \& A. Funk & Johnston et al. 2014 \\
\hline Prillieuxina G. Arnaud & Leprieurina G. Arnaud & Hongsanan et al. 2014 \\
\hline Prosthemium Kunze & Pleomassaria Speg. & Wijayawardene et al. 2014b \\
\hline Pycnopeziza W.L. White \& Whetzel & $\begin{array}{l}\text { Acarosporium Bubák \& Vleugel ex } \\
\text { Bubák (= Chaetalysis Peyrone, } \\
\text { Ciliosira Syd.) }\end{array}$ & Johnston et al. 2014 \\
\hline Pyrenopeziza Fuckel & Cylindrosporium Grev. & Johnston et al. 2014 \\
\hline Rhizothyrium Naumov & Rhizocalyx Petr. & Johnston et al. 2014 \\
\hline Rhytisma Fr. & Melasmia Lév. & Johnston et al. 2014 \\
\hline Scleropezicula Verkley & Cryptosympodula Verkley & Johnston et al. 2014 \\
\hline Seimatosporium Corda & Discostroma clem. & Réblová et al. 2016 \\
\hline Sphaeropsis Sacc. & Phaeobotryosphaeria Speg. & $\begin{array}{l}\text { Phillips et al. 2013; Rossman et al. } \\
\text { 2015b }\end{array}$ \\
\hline Stamnaria Fuckel & Titaeospora Bubák & Johnston et al. 2014 \\
\hline Stilbospora Pers. & Prosthecium Fresen. & $\begin{array}{l}\text { Voglmayr \& Jaklitsch 2014; } \\
\text { Rossman et al. 2015a }\end{array}$ \\
\hline Teratosphaeria Syd. \& P. Syd. & $\begin{array}{l}\text { Colletogloeopsis Crous \& M.J. } \\
\text { Wingf., Kirramyces J. Walker et al. }\end{array}$ & Hyde et al. 2013 \\
\hline Tympanis Tode & $\begin{array}{l}\text { Sirodothis Clem. (= Pleurophomella } \\
\text { Höhn) }\end{array}$ & Johnston et al. 2014 \\
\hline Unguiculariopsis Rehm & Deltosperma W.Y. Zhuang & Johnston et al. 2014 \\
\hline
\end{tabular}

+Coelomycetous morph is in bold

* Not accepted in Réblová et al. 2016

\section{Morphology, phylogeny and evolutionary relationship; impact on coelomycetes}

Unlike sequence-based phylogenetic analyses, morphology does not show evolutionary relationships between genera that have been placed in the one family or higher taxonomic ranks (Sutton 1980). For example, Sutton (1980) placed Lecanosticta and Stilbospora together with 43 other genera (including several genera with conidia bearing appendages) in the suborder Blastostromatineae (i.e. conidiogenesis holoblastic, conidiomata stromatic). Recent sequence-based phylogenetic analyses have shown that Lecanosticta and Stilbospora have distinct lineages, viz. Mycosphaerellaceae, Capnodiales (Quaedvlieg et al. 2014, Wijayawardene et al. 2016) and Stilbosporaceae, Diaporthales (Voglmayr \& Jaklitsch 2014; Wijayawardene et al. 2016), respectively. No asexual genera were placed in a natural classification system prior to $1990 \mathrm{~s}$ and instead were treated as a distinct group, i.e. sub kingdom Deuteromycotina (Ainsworth 1966) although Kendrick (1989) objected to this separate, artificial placement.

Recent phylogenetic studies have shown a complicated picture on generic boundaries drawn from earlier morphology-based studies and this is presented as follows. 
1. Morphologically similar but phylogenetically distinct genera

a. Camarosporium-like taxa including Neocamarosporium, Paracamarosporium, Pseudocamarosporium, Didymellocamerosporium.

b. Phoma-like taxa

2. Morphologically distinct genera (in conidial morphology) but close in phylogeny

a. Camarosporium sensu stricto is a well-known genus with dematiaceous, muriform conidia. Recent phylogenetic analyses showed that several phragomosporous taxa group in Camarosporium sensu stricto and these will be introduced as Camarosporium species (Wanasinghe et al. in prep).

b. Swart \& Williamson (1983) established Vermisporium with hyaline to sub-hyaline, uniformly thin-walled conidia, which are 10-20 times as long as they are wide. Nag Raj (1993) accepted Vermisporium as a distinct genus and recognised ten species. However, Barber et al. (2011) showed that the type species of Vermisporium, V. walkeri H.J. Swart \& M.A. Will. and several other species clusters with Seimatosporium sensu stricto (which has 2-4 septate, brown conidia) and thus were treated as a synonym of Seimatosporium. Therefore, it is essential to rely largely on phylogenetic analyses in the introduction of species or genera.

\section{One fungus, one name}

The dual nomenclature system (Saccardo 1904) of allowing a valid name for both the sexual and asexual morph of a species, ended on 30 July 2011 when the 'one fungus, one name' concept was implemented (Hawksworth 2012, Wingfield et al. 2012). Future usage of pleomorphic genera including coelomycetous asexual morphs have been proposed in Johnston et al. (2014), Wijayawardene et al. (2014b), Maharachchikumbura et al. (2015, 2016), Réblová et al. (2016), Rossman et al. (2015a, b). In Table 4, we summarize the adopted names of pleomorphic coelomycetous genera.

\section{Future challenges}

In traditional fungal taxonomy, based on morphology, culture-based studies were not common and most historic genera or species lack cultures. Thus, molecular sequences are unavailable for most of these taxa. Hence, re-collecting of historic species and epitypification is a significant challenge for future DNA-based studies. The lack of type specimens or specimens in poor condition also complicates advancement and thus, neotypification and epitypification are essential (Ariyawansa et al. 2015).

There are many habitats where the asexual coelomycetous fungi have been poorly studied due to the previous difficulties in identifying taxa. Coelomycetes are common in freshwater habitats (Wijayawardene et al. 2016), but are rarely identified beyond genus (e.g. Phoma sp.). There are also many marine coelomycetes (Jones et al. 2015), but very little is known concerning their taxonomic affinities and they are often only identified to genus level. For example, Phomopsis mangrovei needs recollecting as it is probably not a Diaporthe species. Even the coelomycetes on leaf litter are rarely named beyond genus in ecological studies (e.g. Neocamarosporium) and this need revisiting.

Some genera, such as lichenicolous taxa, cannot be grown on artificial media and these provide a huge challenge. Hence, direct sequencing methods need to be devised and carried out.

Another area that need to be studied is the evolution of coelomycetous genera and species related with their hosts. In a recent special issue of Mycosphere on evolution and ranking, three papers dealt with evolution of Dothideomycetes families with coelomycete morphs (Hongsanan et al. 2016, Mapook et al. 2016, Phukhamsakda et al. 2016b). However, the evolution of phytopathogenic genera, such as Colletotrichum, Diaporthe and others with their hosts, now that we have ample molecular data (Udayanga et al. 2012, Damm et al. 2014) could be an interesting topic for future research. 


\section{Acknowledgements}

The research is supported by the projects of National Natural Science Foundation of China (No. 31560489), Fundamental Research on Science and Technology, Ministry of Science and Technology of China (2014FY120100), the Program for New Century Excellent Talents in University (NCET-13-0748), the Scientific and Technological Personnel Training Program of Guizhou Province (No. 201341) and postgraduate education innovation program of Guizhou Province (ZYRC [2014]004). Alan JL Phillips acknowledges the support from Biosystems and Integrative Sciences Institute (BioISI, FCT/UID/ Multi/04046/2013). B.D. Shenoy acknowledges the funding support under Indo-Thailand collaborative project (THAI-1205) from Department of Science and Technology, Govt. of India.

\section{References}

Abd-Elsalam KA, Yassin MA, Moslem MA, Bahkali AH et al. 2010 - Culture collections, the new herbaria for fungal pathogens. Fungal Diversity 45, 21-32.

Ainsworth GC. 1966 - A general purpose classification of fungi. Bibliography of Systematic Mycology 1, 1-4

Alves A, Linaldeddu BT, Deidda A, Scanu B, Phillips AJ. 2014 - The complex of Diplodia species associated with Fraxinus and some other woody hosts in Italy and Portugal. Fungal Diversity $67,143-56$.

Ariyawansa HA, Hawksworth DL, Hyde KD, Jones EBG et al. 2014 - Epitypification and neotypification: guidelines with appropriate and inappropriate examples. Fungal Diversity 69, 57-79.

Ariyawansa HA, Hyde KD, Jayasiri SC, Buyck B et al. 2015 - Fungal diversity notes 111-252 taxonomic and phylogenetic contributions to fungal taxa. Fungal Diversity 75, 27-274

Aveskamp MM, de Gruyter J, Woudenberg JHC, Verkley GJ, Crous PW. 2010 - Highlights of the Didymellaceae: A polyphasic approach to characterize Phoma and related pleosporalean genera. Studies in Mycology 65, 1-60.

Barber PA, Crous PW, Groenewald JZ, Pascoe IG, et al. 2011 - Reassessing Vermisporium (Amphisphaeriaceae), a genus of foliar pathogens of Eucalypts. Persoonia 27, 90-118.

Boerema GH, Gruyter J de, Noordeloos ME, Hamers MEC. 2004 - Phoma identification manual. Differentiation of specific and infra-specific taxa in culture. CABI publishing, Wallingford, U.K.

Boerema GH. 1997 - Contributions towards a monograph of Phoma (Coelomycetes) - V. Subdivision of the genus in sections. Mycotaxon 64, 321-333.

Chen Q, Jiang JR, Zhang GZ, Cai L, Crous PW. 2015 - Resolving the Phoma enigma. Studies in Mycology 82, 137-217.

Chomnunti P, Schoch CL, Aguirre-Hudson B, Ko Ko TW et al. 2011 - Capnodiaceae. Fungal Diversity 51, 103-134.

Crespo A, Lumbsch HT. 2010 - Cryptic species in lichen-forming fungi. IMA fungus 1, 167-70.

Crous PW, Carris LM, Giraldo A, Groenewald JZ et al. 2015a - The Genera of Fungi - fixing the application of the type species of generic names -G2: Allantophomopsis, Latorua, Macrodiplodiopsis, Macrohilum, Milospium, Protostegia, Pyricularia, Robillarda, Rotula, Septoriella, Torula, and Wojnowicia. IMA Fungus 1, 163-198.

Crous PW, Schoch CL, Hyde KD, Wood AR et al. 2009- Phylogenetic lineages in the Capnodiales. Studies in Mycology 64, 17-47

Crous PW, Schumacher RK, Wingfield MJ, Lombard L et al. 2015b - Fungal Systematics and Evolution: FUSE 1. Sydowia 67, 81-118

Crous PW, Summerell BA, Swart L, Denman S et al. 2011 - Fungal pathogens of Proteaceae. Persoonia 27, 20-45.

Crous PW, Wingfield MJ, Burgess TI, Hardy GS et al. 2016 - Fungal Planet description sheets: 469-557; Persoonia 37, 218-403. 
Crous PW, Wingfield MJ, Guarro J, Cheewangkoon R et al. 2013 -Fungal Planet description sheets: 154-213. Persoonia 31, 188-296.

Crous PW, Wingfield MJ, Le Roux JJ, Richardson DM et al. 2015c - Fungal planet description sheets: 371-399. Persoonia 35:264-327

Dai DQ, Phookamsak R, Wijayawardene NN, Li WJ et al. 2016 - Bambusicolous fungi. Fungal Diversity $82,1-105$.

Damm U, Cannon PF, Woudenberg JH, Crous PW. 2012a - The Colletotrichum acutatum species complex. Studies in Mycology 73, 37-113.

Damm U, Cannon PF, Woudenberg JH, Johnston PR et al. 2012b - The Colletotrichum boninense species complex. Studies in Mycology 73, 1-36.

Damm U, O'Connell RJ, Groenewald JZ, Crous PW. 2014 - The Colletotrichum destructivum species complex -hemibiotrophic pathogens of forage and field crops. Studies in Mycology 79, 49-84.

Dayarathne MC, Boonmee S, Braun U, Crous PW, et al. 2016 - Taxonomic utility of old names in current fungal classification and nomenclature: Conflicts, confusion \& clarifications. Mycosphere 7, 1622-1648.

de Gruyter J, Aveskamp MM, Woudenberg JHC, Verkley GJM et al. 2009 - Molecular phylogeny of Phoma and allied anamorph genera: Towards a re-classification of the Phoma complex. Mycological Research 113, 508-519.

de Gruyter J, Woudenberg JHC, Aveskamp MM, Verkley GJM et al. 2013 - Redisposition of Phoma-like anamorphs in Pleosporales. Studies in Mycology 75, 1-36.

de Gruyter J, Woudenberg JHC, Aveskamp MM, Verkley GJM, Groenewald JZ, et al. 2010 Systematic reappraisal of species in Phoma section Paraphoma, Pyrenochaeta and Pleurophoma. Mycologia 102, 1066-1081.

Dissanayake AJ, Phillips AJL, Li XH, Hyde KD. 2016 - Botryosphaeriaceae: Current status of genera and species. Mycosphere 7, 1001-1073.

Ellis JB, Everhart BM. 1900 - New species of fungi from various localities with notes on some published species. Bulletin of the Torrey Botanical Club 27, 49-64.

Hawksworth DL. 2012 - Managing and coping with names of pleomorphic fungi in a period of transition. Mycosphere 3, 143-155.

Hongsanan S, Li YM, Liu JK, Hofmann T et al. 2014 - Revision of Asterinales. Fungal Diversity $68,1-68$.

Hongsanan S, Sánchez-Ramírez S, Crous PW, Ariyawansa HA et al. 2016 - The evolution of fungal epiphytes. Mycosphere 7, 1690-1712.

Hyde KD, Hongsanan S, Jeewon R, Bhat DJ et al. 2016 - Fungal diversity notes 367-490: taxonomic and phylogenetic contributions to fungal taxa. Fungal Diversity 80, 1-270.

Hyde KD, Jones EBG, Lui JK, Ariyawansa H et al. 2013 - Families of Dothideomycetes. Fungal Diversity 63, 1-313.

Hyde KD, McKenzie EHC, Ko Ko TW. 2011 - Towards incorporating anamorphic fungi in a natural classification - checklist and notes for 2010. Mycosphere 2, 1-88.

Hyde KD, Nilsson RH, Alias SA, Ariyawansa HA et al. 2014 - One stop shop: backbones trees for important phytopathogenic genera: I. Fungal Diversity 67, 21-125.

Index Fungorum 2017 - http://www.indexfungorum.org/Names/Names

Jayawardena RS, Hyde KD, Damm U, Cai L et al. 2016 - Notes on currently accepted species of Colletotrichum. Mycosphere 7, 1192-1260.

Jeewon R, Hyde KD 2016 - Establishing species boundaries and new taxa among fungi: recommendations to resolve taxonomic ambiguities. Mycosphere 7, 1669-1677.

Johnston PR, Seifert KA, Stone JK, Rossman AY, Marvanová L. 2014 - Recommendations on generic names competing for use in Leotiomycetes (Ascomycota). IMA Fungus 5, 91-120.

Jones EBG, Suetrong S, Sakayaroj J, Bahkali AH et al. (2015) Classification of marine Ascomycota, Basidiomycota, Blastocladiomycota and Chytridiomycota. Fungal Divers 73:172 
Kendrick WB, Nag Raj TR. 1979 - Morphological terms in fungal imperfecti. The whole fungus (ed. By Kendrick WB): Nat. Mus. Canada, and Kananaskis Foundation.

Kendrick WB. 1989 - Subdivision Deuteromycotina a fungal chimera. Sydowia 41, 6-14

Kendrick WB. 2000 - The Fifth Kingdom, 3rd edn. Focus Publishing, Newbury.

Kirk PM, Cannon PF, Minter DW, Stalpers JA. 2008 - Ainsworth \& Bisby's Dictionary of the Fungi, 10th edn. CABI, Wallingford.

Li GJ, Hyde KD, Zhao RL, Hongsanan S et al. 2016 - Fungal diversity notes 253-366: taxonomic and phylogenetic contributions to fungal taxa. Fungal Diversity 78, 1-237.

Li WJ, Bhat DJ, Camporesi E, Tian Q et al. 2015 - New asexual morph taxa in Phaeosphaeriaceae. Mycosphere 6, 681-708.

Liu F, Wang M, Damm U, Crous PW, Cai L. 2016 - Species boundaries in plant pathogenic fungi: a Colletotrichum case study. BMC Evolutionary Biology 16, 81.

Maharachchikumbura SS, Hyde KD, Jones EBG, McKenzie EHC et al. 2015 - Towards a natural classification and backbone tree for Sordariomycetes. Fungal Diversity 72, 199-301.

Maharachchikumbura SSN, Guo LD, Cai L, Chukeatirote E et al. 2012 - A multi-locus backbone tree for Pestalotiopsis, with a polyphasic characterization of 14 new species. Fungal Diversity $56,95-129$.

Maharachchikumbura SSS, Hyde KD, Jones EBG, McKenzie EHC et al. 2016 - Families of Sordariomycetes. Fungal Diversity 79, 1-317.

Mapook A, Hyde KD, Hongsanan S, Phukhamsakda C et al. 2016 - Palawaniaceae fam. nov., a new family (Dothideomycetes, Ascomycota) to accommodate Palawania species and their evolutionary time estimates. Mycosphere 7, 1732-1745.

Nag Raj TR. 1993 - Coelomycetous Anamorphs with Appendage-bearing Conidia. Mycologue Publications, Waterloo.

Phillips AJ, Lopes J, Abdollahzadeh J, Bobev S, Alves A. 2012 - Resolving the Diplodia complex on apple and other Rosaceae hosts. Persoonia 29, 29-38.

Phillips AJL, Alves A, Abdollahzadeh J, Slippers B et al. 2013 - The Botryosphaeriaceae: genera and species known from culture. Studies in Mycology 76, 51-167.

Phillips AJL, Alves A, Pennycook SR, Johnston PR et al. 2008 - Resolving the phylogenetic and taxonomic status of dark-spored teleomorph genera in the Botryosphaeriaceae. Persoonia 21, $29-55$.

Phukhamsakda C, Ariyawansa HA, Phillips AJ, Wanasinghe DN et al. 2016a - Additions to Sporormiaceae: Introducing two novel genera, Sparticola and Forliomyces, from Spartium. Cryptogamie Mycologie 37, 75-97.

Phukhamsakda C, Hongsanan S, Ryberg M, Ariyawansa HA et al. 2016b - The evolution of Massarineae with Longipedicellataceae fam. nov. Mycosphere 7, 1713-1731.

Quaedvlieg W, Binder M, Groenewald JZ, Summerell BA et al. 2014 - Introducing the consolidated species concept to resolve species in the Teratosphaeriaceae. Persoonia 33, 140.

Réblová M, Miller AN, Rossman AY, Seifert KA et al. 2016 - Recommendations for competing sexual-asexually typified generic names in Sordariomycetes (except Diaporthales, Hypocreales, and Magnaporthales). IMA Fungus 7, 131-153.

Rossman AY, Adams GC, Cannon PF, Castlebury LA et al. 2015a - Recommendations of generic names in Diaporthales competing for protection or use. IMA Fungus 6, 145-154.

Rossman AY, Crous PW, Hyde KD, Hawksworth DL et al. 2015b - Recommended names of pleomorphic genera in Dothideomycetes. IMA Fungus 6, 507-523.

Saccardo PA. 1880 - Conspectus generum fungorum Italiae inferiorum nempe ad Sphaeropsideas, Melanconieas et Hyphomyceteas pertinentium systemate sporologico dispositorum. Michelia $2,1-38$.

Saccardo PA. 1884 - Sylloge Fungorum: Sylloge Sphaeropsidearum et Melanconiearum. Sylloge Fungorum 3, 1-840. 
Saccardo PA. 1904 - De Diagnostica et nomenclatura mycologica, Admonita quaedam. Ann Mycol 2:195-198 [English translation by Clements FE (1904) J Mycol 10: 109-112].

Schoch CL, Crous PW, Groenewald JZ, Boehm EWA et al. 2009 - A class-wide phylogenetic assessment of Dothideomycetes. Studies in Mycology 64, 1-15.

Seifert K, Morgan-Jones G, Gams W, Kendrick B. 2011 - The genera of hyphomycetes. CBSKNAW Fungal Biodiversity Centre Utrecht, The Netherlands.

Senanayake IC, Maharachchikumbura SSN, Hyde KD, Bhat JD et al. (2015) Towards unraveling relationships in Xylariomycetidae (Sordariomycetes). Fungal Diversity 73, 73-144.

Sharma G, Pinnaka AK, Shenoy BD. 2015 - Resolving the Colletotrichum siamense species complex using ApMat marker. Fungal Diversity 71, 247.

Slippers B, Crous PW, Denman S, Coutinho TA et al. 2004 - Combined multiple gene genealogies and phenotypic characters differentiate several species previously identified as Botryosphaeria dothidea. Mycologia 96, 83-101.

Spooner BM, Kirk PM. 1982 - Taxonomic notes on Excipularia and Scolicosporium. Transactions of the British Mycological Society 78, 247-257.

Sutton BC, Dyko BJ. 1989 - Revision of Hendersonula. Mycological Research 93, 466-488.

Sutton BC. 1975 - Coelomycetes V. Coryneum. Mycological Papers 138, 1-224.

Sutton BC. 1980 - The Coelomycetes: fungi imperfecti with pycnidia, acervuli and stromata. Commonwealth Mycological Institute, Kew.

Swart HJ, Williamson MA. 1983 - Australian leaf-inhabiting fungi XVI. Vermisporium, a new genus of coelomycetes on Eucalyptus leaves. Transactions of the British Mycological Society 81, 491-50.

Tibpromma S, Hyde KD, Jeewon R, Maharachchikumbura SS et al. 2017 - Fungal diversity notes 491-602: taxonomic and phylogenetic contributions to fungal taxa. Fungal Diversity 83, 1261.

Udayanga D, Castlebury LA, Rossman AY, Chukeatirote E et al. 2014 - Insights into the genus Diaporthe: phylogenetic species delimitation in the D. eres species complex. Fungal Diversity 67, 203-229.

Udayanga D, Liu XZ, Crous PW, McKenzie EHC et al. 2012 - A multi-locus phylogenetic evaluation of Diaporthe (Phomopsis) Fungal Diversity 56, 157-171.

Verkley GJM, da Silva M, Wicklow DT, Crous PW. 2004 - Paraconiothyrium, a new genus to accommodate the mycoparasite Coniothyrium minitans, anamorphs of Paraphaeosphaeria, and four new species. Studies in Mycology 50, 323-335.

Verkley GJM, Renfurm R, Göker M, Stielow JB. 2014 - Novel genera and species of coniothyrium-like fungi in Montagnulaceae (Ascomycota). Persoonia 32, 25-51.

Voglmayr H, Jaklitsch W. 2014 - Stilbosporaceae resurrected: generic reclassification and speciation. Persoonia 33, 61-82.

Wanasinghe DN, Jones EBG, Camporesi E, Boonmee S et al. 2014 - An exciting novel member of Lentitheciaceae in Italy from Clematis vitalba. Cryptogamie Mycologie 35, 323-337.

Weir BS, Johnston PR, Damm U. 2012 - The Colletotrichum gloeosporioides species complex. Studies in Mycology 73, 115-180.

Wijayawardene DNN, McKenzie EHC, Hyde KD. 2012 - Towards incorporating anamorphic fungi in a natural classification - checklist and notes for 2011. Mycosphere 3, 157-228.

Wijayawardene NN, Bhat DJ, Hyde KD, Camporesi E et al. 2014a-Camarosporium sensu stricto in Pleosporinae, Pleosporales with two new species. Phytotaxa 183, 16-26.

Wijayawardene NN, Camporesi E, Song Y, Dai DQ et al. 2013 - Multi-gene analyses reveal taxonomic placement of Scolicosporium minkeviciusii in Phaeosphaeriaceae (Pleosporales). Cryptogamie Mycologie 34, 357-366.

Wijayawardene NN, Crous PW, Kirk PM, Hawksworth DL et al. 2014b - Naming and outline of Dothideomycetes-2014 including proposals for the protection or suppression of generic names. Fungal Diversity 69, 1-55. 
Wijayawardene NN, Hyde KD, Bhat DJ, Camporesi E et al. 2014c - Camarosporium-like species are polyphyletic in Pleosporales; introducing Paracamarosporium and Pseudocamarosporium gen. nov. in Montagnulaceae. Cryptogamie Mycologie 35, 177-198.

Wijayawardene NN, Hyde KD, Camporesi E, Bhat DJ et al. 2015 - Additions to brown spored coelomycetous taxa in Massarinae. Pleosporales: introducing Phragmocamarosporium gen nov and Suttonomyces gen. nov. Cryptogamie Mycologie 36, 213-224.

Wijayawardene NN, Hyde KD, Rajeshkumar KC, Hawksworth DL et al. 2017 - Notes for genera Ascomycota. Fungal Diversity 85 (in press).

Wijayawardene NN, Hyde KD, Wanasinghe DN, Papizadeh M et al. 2016 - Taxonomy and phylogeny of dematiaceous coelomycetes. Fungal Diversity 77, 1-316.

Wikee S, Udayanga D, Crous PW, Chukeatirote E et al. 2011 - Phyllosticta an overview of current status of species recognition. Fungal Diversity 51, 43-61.

Wingfield MJ, De Beer ZW, Slippers B, Wingfield BD et al. 2012 - One fungus one name promotes progressive plant pathology. Molecular Plant Pathology 13, 604-613.

Yang YL, Liu ZY, Cai L, Hyde KD et al. 2009 - Colletotrichum anthracnose of Amaryllidaceae. Fungal Diversity 39, 123-146. 